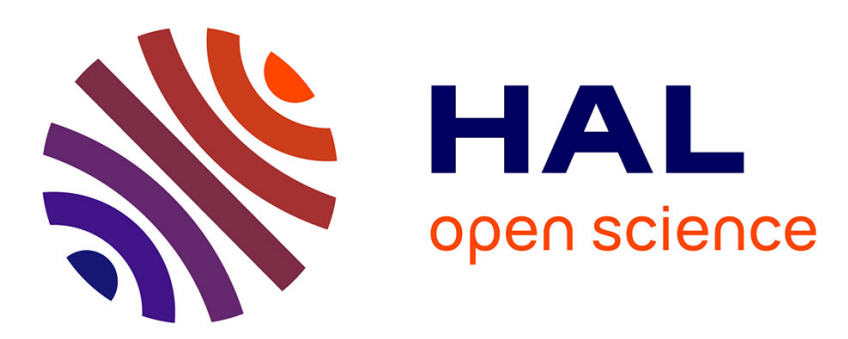

\title{
Characterization of milk from feeding systems based on herbage or corn silage with or without flaxseed and authentication through fatty acid profile
}

Catherine Hurtaud, Marion Dutreuil, Mauro Coppa, Claire Agabriel, Bruno Martin

\section{To cite this version:}

Catherine Hurtaud, Marion Dutreuil, Mauro Coppa, Claire Agabriel, Bruno Martin. Characterization of milk from feeding systems based on herbage or corn silage with or without flaxseed and authentication through fatty acid profile. Dairy Science \& Technology, 2014, 94 (2), pp.103-123. 10.1007/s13594-013-0147-0 . hal-01210540

\author{
HAL Id: hal-01210540 \\ https://hal.science/hal-01210540
}

Submitted on 27 May 2020

HAL is a multi-disciplinary open access archive for the deposit and dissemination of scientific research documents, whether they are published or not. The documents may come from teaching and research institutions in France or abroad, or from public or private research centers.
L'archive ouverte pluridisciplinaire HAL, est destinée au dépôt et à la diffusion de documents scientifiques de niveau recherche, publiés ou non, émanant des établissements d'enseignement et de recherche français ou étrangers, des laboratoires publics ou privés. 


\title{
Characterization of milk from feeding systems based on herbage or corn silage with or without flaxseed and authentication through fatty acid profile
}

\author{
Catherine Hurtaud • Marion Dutreuil • \\ Mauro Coppa • Claire Agabriel • Bruno Martin
}

Received: 26 February 2013 / Revised: 27 August 2013 / Accepted: 27 August 2013 /

Published online: 16 October 2013

(C) INRA and Springer-Verlag France 2013

\begin{abstract}
Adapting feeding system is an effective way for improving the nutritional quality of milk as currently intended by dairy industry. The objectives of this work were (1) to characterize milk from feeding systems based on herbage or corn silage with or without flaxseed and (2) to authenticate the milk from the three systems on the basis of the fatty acid (FA) profile. Bulk milk samples were collected five times on 24 farms in the West of France. Farms were classified according to three feeding systems: "Herbage" system with herbage as the only forage source; "Corn silage" system with corn silage as the main forage (33.6\% of DM grass based); "Corn silage+ flaxseed" system with corn silage as the main forage (24\% of DM grass based) supplemented with 690 g.day ${ }^{-1} \cdot \mathrm{cow}^{-1}$ of extruded flaxseed. The "Corn silage+ flaxseed" system had higher milk yield and lower milk fat and protein contents.
\end{abstract}

C. Hurtaud $(\bowtie) \cdot$ M. Dutreuil

INRA, UMR1348 Physiologie, Environnement et Génétique pour l'Animal et les Systèmes d'Elevage, 35590 Saint-Gilles, France

e-mail: catherine.hurtaud@rennes.inra.fr

C. Hurtaud · M. Dutreuil

Agrocampus Ouest, UMR1348 Physiologie, Environnement et Génétique pour l'Animal et les Systèmes d'Elevage, 35000 Rennes, France

M. Coppa $\cdot$ C. Agabriel • B. Martin

INRA, UMR 1213 Herbivores, 63122 Saint Genès Champanelle, France

M. Coppa $\cdot$ C. Agabriel $\cdot$ B. Martin

VetAgro Sup, UMR1213 Herbivores, Clermont Université, BP 10448, 63000 Clermont-Ferrand, France

Present Address:

M. Coppa

Department of Agricultural, Forest and Food Sciences, University of Turin, Via Leonardo da Vinci, 44-10095 Grugliasco, Turin, Italy 
Compared to milk from "Herbage system", milk from "Corn silage+flaxseed" system was rich in mono- and poly-unsaturated FAs, trans FAs, C18:0, isomers of C18:1 and C18:2 (respectively $+13,+21,+28,+13,+44,+54$ percentage units), whereas milk from the "Herbage" system was rich in odd, branched chain FAs and cis-9,trans-11CLA (respectively $+51,+55$ and +15 percentage units compared to milk from "Corn silage+flaxseed" system). Milk FA composition from "Herbage" and "Corn silage" systems was more variable throughout the year than that from the "Corn silage+ flaxseed" system because of the incorporation of more pasture during spring and summer. The linear discriminant analysis performed on FAs permitted to differentiate milk from each system with only $2.5 \%$ of milks misclassified, even for milk from the "Herbage" and "Corn silage+flaxseed" systems, which had a similar C18:3 content. This study showed that it is possible to characterize milk from different feeding systems and especially to differentiate one from another based on their composition of some milk FAs.

Keywords Bulk milk · Fatty acids $\cdot$ Authentication $\cdot$ Feeding system $\cdot$ Dairy cow

$\begin{array}{ll}\text { Abbreviations } \\ \text { ALA } & \alpha \text {-Linolenic acid C18:3 } \\ \text { AU } & \text { Animal unit } \\ \text { BW } & \text { Body weight } \\ \text { CLA } & \text { Conjugated linoleic acid } \\ \text { DHI } & \text { National dairy herd information } \\ \text { DIM } & \text { Days in milk } \\ \text { F } & \text { Fisher's } F \\ \text { FA } & \text { Fatty acid } \\ \text { IC } & \text { Intake capacity } \\ \text { LDA } & \text { Linear discriminant analysis } \\ \text { NPN } & \text { Non-protein nitrogen } \\ \text { NCN } & \text { Non-casein nitrogen } \\ \text { SD } & \text { Standard deviation } \\ \text { SEM } & \text { Standard error to the mean } \\ \text { RMSE } & \text { Root-mean-square error } \\ \text { VFA } & \text { Volatile fatty acid }\end{array}$

\section{Introduction}

Milk and other dairy products are an important part of the everyday diet for people living in industrialized countries (C.N.I.E.L 2013). Milk is known for its nutritional qualities: protein content (Clare and Swaisgood 2000), calcium content and vitamin contents (A, D, B2 and B12) (Martin et al. 2009). However, fat from milk has a bad image because of its high content in saturated fatty acids (FA) which were supposed to be atherogenic even if no negative effect has been proven (Siri-Tarino et al. 2010) and if some of them (C4:0, C6:0, C8:0, C14:0) have interesting nutritional values (Legrand 2010). Nowadays, one of the objectives of dairy industry is still to improve the nutritional quality of milk fat by reducing saturated FAs, particularly the atherogenic palmitic acid (Nicolis 1997), in favor of polyunsaturated FAs. The main goal is 
to increase the content of n-3 FA series, including $\alpha$-linolenic acid (ALA), and conjugated linoleic acid (CLA), including rumenic acid. Factors affecting the proportions of FAs in the milk are well known and include mainly feeding management (Chilliard et al. 2007; Coppa et al. 2013). Dhiman et al. (1999), Leiber et al. (2005) and Couvreur et al. (2006) have shown that increasing the percentage of herbage in a diet including corn silage is associated with a linear increase in ALA and rumenic acid contents in milk fat. Likewise, extruded flaxseed particularly rich in ALA as a supplement to corn silage induces an increase in milk ALA content. An increase of 0.3 to 1.3 percentage units in milk ALA content was obtained by Brunschwig et al. (2010) in experimental conditions where the amount of lipids from flaxseed fed to the cows was higher than the one fed on commercial dairy farms (respectively $363 \mathrm{vs}$ 250 g.day ${ }^{-1}$. .ow $^{-1}$ on average) (Schori et al. 2006; Hurtaud et al. 2010b). Moreover, literature about the variability of milk fatty acid composition from farms where the diet is based on corn silage supplemented with flaxseed compared with farms where the diet is based on corn silage and a conventional concentrate or with farms using herbage (preserved or grazed) is lacking. Farms from three different feeding systems representing dairy farming in Western France were selected: one feeding system based on corn silage mainly all year called "Corn silage", one feeding system based on herbage mainly all year (preserved or grazed) called "Herbage" system and one feeding system from the French label "Bleu Blanc Coeur" "based on corn silage supplemented mainly with flaxseed called "Corn silage+flaxseed". The aims of this work were (1) to characterize the "Corn silage+flaxseed" feeding systems and the seasonal evolution during the year of the bulk milk composition (including a detailed FA profile), in comparison to the conventional "Corn silage" and "Herbage" systems; (2) to authenticate the origin of the milk from the three systems using the FA profile.

\section{Materials and methods}

This study was carried out using survey data and milk sampling from commercial dairy farms in Western France between November 2007 and September 2008.

\subsection{Selection of farms}

The production system of each dairy farm (29) was described in a preliminary survey in November 2007. Questions were asked about (1) farm characteristics (area, altitude, housing and milking equipment, milk quota, other animals); (2) herd characteristics (breed, number of dairy cows, number of heifers, calving periods); (3) forage management (forage characteristics, forage harvesting and storage, cutting and grazing periods, and the cropping rotation during the year or other companion crops). At the end of this survey, ten farms in the "Corn silage" system, ten farms in the "Herbage" system and four farms in the "Corn silage+flaxseed" system were selected for the main study.

\footnotetext{
${ }^{1}$ The contractual conditions between farmers and the animal food industry include doubling the amount of C18:3 in the milk in comparison to a standard feeding management based on corn silage, having a ratio $\omega 6 / \omega 3$ lower than 5 and decreasing the amount of palmitic acid in the milk.
} 


\subsection{Milk samples on farms}

Bulk milk samples were collected on farms five times during the year 2008: two times in winter (first week of January and of February), once in spring (first week of May) and two times in summer (first 2 weeks of July and first week of September).

Milk was collected on farm from the bottom of the tank containing an even number of milkings (two, four or six) after 5 min of mixing. Each milk sample was about $2 \mathrm{~L}$.

At the time of sampling, farmers were asked to describe the cow feeding as well as herd management. Questions were about (1) quantity of milk delivered; (2) herd characteristics (number of dairy cows, calving distribution, stage of lactation); (3) herd feeding (quantity and nature of forages, concentrates, minerals with a focus on grazing: duration, type of pasture, beginning and end of use of a paddock).

Stage of lactation For the 17 farms with national dairy herd information (DHI) records, the closest values of days in milk (DIM) were used to estimate the average stage of lactation of the herd at the time of milk sampling. For the seven farms without DHI records (six in the "Herbage" system and one in the "Corn silage" system), average stage of lactation at the time of milk sample was calculated using monthly calving data.

Variables description Five times of sampling were defined: January, February, May, July and September. Five types of forages were defined: fresh herbage (grazing or green chop), hay, preserved herbage (silage, baleage, haylage...), total herbage (includes fresh and preserved herbage, as well as hay) and corn silage. The percentage of each of those five forages in the diet was calculated. Each type of concentrate was defined, and the percentage of concentrate in the diet was calculated.

Pasture intake To describe feeding at the time of milk sampling, farmers estimated the daily amounts of preserved forage and concentrates eaten by the cows. To estimate dry matter intake from pasture, the average intake capacity (IC) of every herd was calculated (INRA 2007) using the following equation:

$$
\mathrm{IC}=[(13.9+(0.015 \times \mathrm{BW}-600))+(0.15 \times \text { potMP })+(1.5 \times(3-\mathrm{BCS}))] \times \mathrm{WeF}
$$

with:

- BW, the body weight of the cows. We used $600 \mathrm{~kg}$ for first lactation cows and $680 \mathrm{~kg}$ for multiparous cows.

- $\quad$ potMP, the potential milk production (INRA 2007). It was calculated using INRA 2007 tables with the average milk production during 305 days and the stage of lactation.

- BCS, the body condition score. For the herds in the "Corn silage" and "Corn silage+ flaxseed" system, a score of 2.75 was used for cows under 100 DIM, 3 was used for cows between 100 and 260 DIM and 3.5 was used for cows after 260 DIM. For the herds in the "Herbage" system, a score of 2.25 was used for cows under 100 DIM, 2.5 
was used for cows between 100 and 260 DIM and 2.75 was used for cows after 260 DIM (Delaby, personal communication).

- WeF: weighing factor $=$ percentage primiparous cows $\times \mathrm{WeFp}+$ percentage multiparous dairy cows $\times \mathrm{WeFm}$ where:

$$
\begin{aligned}
& \text { WeFp (for primiparous cows) } \\
& =\left(0.6+(1-0.6) \times\left(1-\exp ^{(-0.16 \times \text { week of lactation })}\right)\right) \\
& \times\left(0.8+0.2 \times\left(1-\exp ^{(-0.25 \times(40-\text { week of gestation })}\right)\right) \\
& \times\left(-0.1+1.1 \times\left(1-\exp ^{(-0.08 \times 32)}\right)\right)
\end{aligned}
$$

and

$$
\begin{aligned}
& \text { WeFm (for multiparous cows) } \\
& =\left(0.7+(1-0.7) \times\left(1-\exp ^{(-0.16 \times \text { week of lactation })}\right)\right) \\
& \times\left(0.8+0.2 \times\left(1-\exp ^{(-0.25 \times(40-\text { week of gestation })}\right)\right) \\
& \times\left(-0.1+1.1 \times\left(1-\exp ^{(-0.08 \times 60)}\right)\right)
\end{aligned}
$$

We estimated pasture dry matter intake by subtracting the quantity of preserved forage and concentrate from the IC using a filling value of 0.98 for corn silage, 1.05 for green forages (hay, herbage silage and baleage) and 0.4 for concentrates (INRA 2007).

\subsection{Milk analyses}

Milk samples were analysed the same day they were collected for the samples taken in the morning or the next day, after being kept refrigerated at $4{ }^{\circ} \mathrm{C}$ overnight, for the ones taken in the evening. Fat, protein and lactose contents were obtained using an infrared analyser (Milkoscan FT+, Foss Electric, Hillerød, Denmark) calibrated with milks for connection with standard methods (AFNOR NF V04-210 (2000) for milk fat content, AFNOR NF V04-216 (2011) for milk protein content and NF ISO 26462/FIL 214 (2010) for lactose content). The FA composition was determined on one replicate by lipid extraction from a $0.5-\mathrm{mL}$ sample of milk fat according to the method described in Bauchart and Duboisset (1983), using $0.5 \mathrm{~mL}$ of an ethanol/ $\mathrm{HCl}(100: 5, v / v)$ solution followed by $5 \mathrm{~mL}$ of hexane. Milk FAs were esterified with $1.0 \mathrm{~mL}$ of a methanol/ $\mathrm{NaOH}$ $(100: 2, v / v)$ solution followed by $1.0 \mathrm{~mL}$ of a methanol boron trifluoride solution $(100: 20, v / v)$ and $2 \mathrm{~mL}$ of hexane (to obtain methyl esters). These methyl esters were extracted with $2 \mathrm{~mL}$ of $n$-hexane and injected into a Varian CP-3800 GC (Varian Inc., Walnut Creek, USA) equipped with a flame ionization detector. The methyl esters of FAs were separated on an SP 2560 fused silica capillary column $(100 \mathrm{~m} \times 0.25 \mathrm{~mm}$ i.d., Supelco Inc., Bellafonte, PA) under the following temperature program: starting at $90{ }^{\circ} \mathrm{C}$ for $7 \mathrm{~min}$, then ramped up $7{ }^{\circ} \mathrm{C} / \mathrm{min}$ to reach $155^{\circ} \mathrm{C}$, then ramped up $3{ }^{\circ} \mathrm{C} / \mathrm{min}$ to reach $235^{\circ} \mathrm{C}$, then held at $235^{\circ} \mathrm{C}$ for $10 \mathrm{~min}$. Both injector and detector temperatures were at $230^{\circ} \mathrm{C}$. Carrier gas was helium. Total nitrogen content, non-protein nitrogen matter 
(NPN), non-casein nitrogen, casein and urea were determined according to the Kjeldahl methods described by Alais (1984). Total and soluble calcium were analysed by atomic absorption spectroscopy on milk and milk ultrafiltrate, respectively (Brûlé et al. 1974).

\subsection{Statistical analysis}

The statistical analysis was performed using the Proc Mixed of SAS (2005). We carried out a covariance analysis for the parameters of milk performance, and milk FA composition as well as the fat, protein and lactose contents measured on farm milk. The co-variable included was the dairy cows' stage of lactation measured at each survey period. The statistical model is as follows:

$$
Y_{i j}=\mu+r_{i}+p_{j}+r_{i} * p_{j}+\operatorname{cov} Y_{i j}+e_{i j}
$$

where $\mu$ is the mean, $r_{i}$ the feeding system effect ("Corn silage", "Herbage", "Corn silage+flaxseed", 2 d.f.), $p_{j}$ the month effect, cov $Y_{i j}$ the stage of lactation and $e_{i j}$ the residual error.

Results were expressed as least square means with standard errors of the means. The significance threshold was set at $P \leq 0.05$ and the trend at $P \leq 0.10$.

In order to choose the potential milk FA candidate to trace the feeding system, a second general linear model (GLM) ANOVA was performed on milk FAs, using just the feeding system as fixed factor, applying the following model:

$$
Y_{i j}=\mu+r_{i}+e_{i j}
$$

where $\mu$ is the mean, $r_{i}$ the feeding system effect ("Corn silage", "Herbage", "Corn silage+flaxseed", 2 d.f.) and $e_{i}$ the residual error.

The FAs having the Fischer's $F$ higher than 20 were used to perform a Linear Discriminant Analysis (LDA). The resulting discrimination functions were validated by the "leave-one-out" method (full cross-validation) using the SPSS for Windows (version 16.0; SPSS Inc., Chicago, IL, USA) software package.

\section{Results}

\subsection{Farm characteristics}

Herbage system Farms in the "Herbage" system operated $62.1 \pm 27.9$ ha $(88 \%$ of which was used to grow forages) with $51.7 \pm 23.1$ cows for an average stocking rate of 1.19 \pm 0.19 animal unit (AU).ha ${ }^{-1}$ of forage area. Those farms had the lowest milk quota $(287,069 \pm 131166 \mathrm{~L})$ and the lowest milk production per cow $\left(5,119 \pm 743\right.$ L.year $\left.^{-1}\right)$. Breeds used on those farms by order of importance were Holstein, Normande, Montbéliarde and Simmental (51.4\%, 36.4\%, 4.6\% and 4.1\%, respectively; Table 1).

Corn silage system Farms in the "Corn silage" system operated $103.6 \pm 46.1$ ha $(67 \%$ of which was used to grow forages) with $67.1 \pm 27.4$ cows for an average stocking rate of $1.61 \pm 0.27$ AU.ha $^{-1}$ of forage area. Those farms had the highest milk quota $(504,140$ 
Table 1 Description of the farms from the three feeding systems investigated in 2008 (data from surveys in November 2007; ten farms in "Herbage" system, ten farms in "Corn silage" System and four farms in "Corn silage+flaxseed" system)

\begin{tabular}{llll}
\hline & Herbage $( \pm \mathrm{SD})$ & Corn silage $( \pm \mathrm{SD})$ & $\begin{array}{l}\text { Corn silage }+ \text { flaxseed } \\
( \pm \mathrm{SD})\end{array}$ \\
\hline Number of investigated farms & 10 & & 4 \\
Number of full-time workers & $1.8 \pm 0.8$ & 10 & $2.0 \pm 0.8$ \\
Number of cows & $51.7 \pm 23.1$ & $6.5 \pm 0.8$ & $45.0 \pm 9.3$ \\
Total agricultural area (ha) & $62.1 \pm 27.9$ & $103.6 \pm 46.1$ & $86.5 \pm 36.1$ \\
Land in cereals, oleaginous and & $6.3 \pm 4.9$ & $30.7 \pm 18.5$ & $30.1 \pm 10.4$ \\
$\quad$ legumes (ha) & & & \\
Land in forages (LIF) (ha) & $54.8 \pm 26.8$ & $69.8 \pm 31.5$ & $50.9 \pm 27.1$ \\
LIF Permanent herbage (\% of LIF) & $26.6 \pm 30.5$ & $7.4 \pm 8.2$ & $16.3 \pm 20.4$ \\
$\quad$ Temporary herbage (\% of LIF) & $73.4 \pm 30.5$ & $55.0 \pm 10.3$ & $41.4 \pm 17.2$ \\
$\quad$ Corn (\% of LIF) & $0.0 \pm 0.0$ & $37.6 \pm 8.8$ & $42.3 \pm 14.1$ \\
Stocking rate (AU.ha ${ }^{-1}$ of LIF) & $1.19 \pm 0.19$ & $1.61 \pm 0.27$ & $1.78 \pm 0.30$ \\
Quota (L.year ${ }^{-1}$ ) & $287,069 \pm 131,166$ & $504,140 \pm 217,202$ & $370,896 \pm 66,486$ \\
Average lactation number & $3.2 \pm 0.65$ & $2.2 \pm 0.18$ & $2.8 \pm 1.31$ \\
Milk yield (L.cow ${ }^{-1}$ per lactation) & $5,119 \pm 743$ & $8,896 \pm 555$ & $10,184 \pm 1,224$ \\
Milk fat content (g.kg ${ }^{-1}$ ) & $40.7 \pm 1.44$ & $40.2 \pm 1.41$ & $37.7 \pm 2.10$ \\
Milk protein content (g.kg ${ }^{-1}$ ) & $32.8 \pm 0.77$ & $32.6 \pm 0.45$ & $31.6 \pm 0.84$ \\
\hline & & & \\
\hline
\end{tabular}

$\pm 217,202 \mathrm{~L})$ and an intermediate milk production per cow $\left(8,896 \pm 555\right.$ L.year $\left.^{-1}\right)$ compared to the farms in the two other systems. The only breed represented on those farms was Holstein (Table 1).

Corn silage+flaxseed system Farms in the "Corn silage+flaxseed" system operated $86.5 \pm 36.1$ ha $(51 \%$ of which was used to grow forages) with $45.0 \pm 9.3$ cows for an average stocking rate of $1.78 \pm 0.30 \mathrm{AU}^{-h^{-1}}$ of forage area. Those farms had an intermediate milk quota compared to the farms in the two other systems $(370,896$ $\pm 66,486 \mathrm{~L})$ but the highest milk production per cow $\left(10,184 \pm 1,224 \mathrm{~L}\right.$ year $\left.{ }^{-1}\right)$. As for the farms in the "Corn silage" system, the only breed represented on those farms was Holstein. Cows received an average of $690 \pm 238$ g.day $^{-1}$ of extruded flaxseed, which correspond to an average of $200 \pm 68$ g.day $^{-1}$ of lipids (Table 1).

\subsection{Feeding system, milk production and composition}

The three systems were really different based on feeding management. The diet composition at each sampling is described in Table 2. On the farms from the "Herbage" system", cows received herbage all year round: preserved herbage as hay, silage or baleage in winter and grazing in spring and summer. The amount of concentrate fed was relatively small: $16 \%$ and $2 \%$ of total DMI in winter and summer, respectively. The type of concentrate fed was mainly based on cereals (corn, oats or mix). On the farms from the two other systems, cows received corn silage all year associated with preserved herbage in winter and end of summer (from $11 \%$ to $20 \%$ of herbage silage or hay of total 


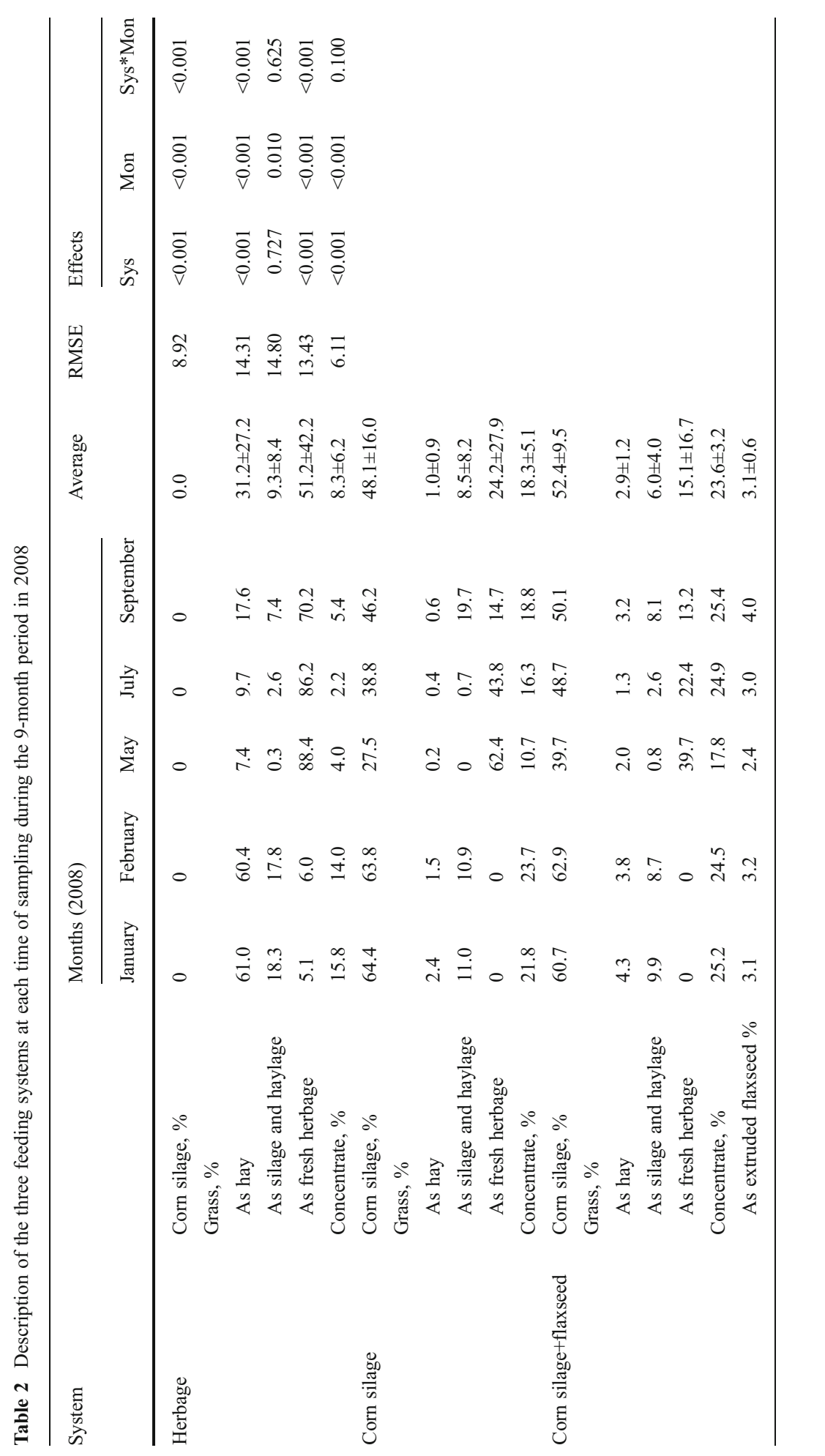


DMI) and with grazing in spring (up to $62 \%$ of total DMI in the "Corn silage" system and up to $40 \%$ of total DMI in the "Corn silage+flaxseed" system). The amount of concentrate fed was about $22 \%$ of DMI in winter and about $17 \%$ in summer for the "Corn silage" system and $25 \%$ of DMI all year for the "Corn silage+flaxseed" system. For the "Corn silage" system, concentrates were made up of soybean meal, cereals (wheat and corn) and alfalfa meal, whereas in the "Corn silage+flaxseed" system, they were made up of soybean meal and rapeseed meal enriched with extruded flaxseed, lupine and alfalfa.

In comparison to the farms in the "Corn silage" system, farms in the "Corn silage+ flaxseed" system had a higher milk production and higher milk lactose content $(+$ 3.9 kg.day ${ }^{-1}$.cow ${ }^{-1}$ and +0.9 g. $\mathrm{kg}^{-1} \cdot$ cow $^{-1}$, respectively) and a lower fat and protein contents ( -1.8 and -0.7 g. $\mathrm{kg}^{-1}$.cow ${ }^{-1}$, respectively) despite higher fat and protein yields $\left(+100\right.$ and +102 g.day ${ }^{-1}$. cow $^{-1}$, respectively; Table 3$)$. In comparison to the farms in the "Corn silage" system, farms in the "Herbage" system had a lower milk production and lower milk lactose content $\left(-9.8 \mathrm{~kg} \cdot \mathrm{day}^{-1}\right.$. $\mathrm{cow}^{-1}$ and $-0.9 \mathrm{~g} \cdot \mathrm{kg}^{-1} \cdot \mathrm{cow}^{-1}$, respectively) but similar fat and protein contents leading to lower fat and protein yields $(-313$ and -410 g.day ${ }^{-1}$.cow ${ }^{-1}$, respectively).

Farms in the "Herbage" system had similar true protein, casein, soluble protein, NPN and calcium contents and casein/true protein ratio to farms in the "Corn silage" system (Table 3). The milk from farms in the "Corn silage+flaxseed" system had a lower true protein content due to a lower casein content and a lower casein/true protein ratio than farms in the "corn silage" system.

Milk from each system was characterized by a specific milk FA profile (Table 4). On average during the year, milk from "Corn silage" system was characterized by a high saturated FA content (70.44\%), especially in C16:0 and short FAs $(<\mathrm{C} 10: 0)$, a low trans FA, ALA and cis- 9 , trans-11 CLA content $(2.62 \%, 0.44 \%$ and $0.44 \%$, respectively), and a high cis-9-C16:1/C16:0 and cis-9-C18:1/C18:0 ratios (0.054 and 2.14, respectively). Milk from "Corn silage+flaxseed" was characterized by a high unsaturated FA content (33.51\%), a high trans FA content (4.51\%), a high C18:0 content (10.89\%), a high content in isomers of C18:1 and C18:2, a low content of branched chain FA (1.26\%) and odd FA $(2.60 \%)$ and a medium content of cis-9, trans-11 CLA $(0.75 \%)$. Milk from the "Herbage" system had intermediate values in unsaturated FA content. It was characterized by a high content of odd FAs $(\geq \mathrm{C} 15)$, of branched chain FAs (iso $\mathrm{C} 15: 0$, anteiso $\mathrm{C} 15: 0$, iso $\mathrm{C} 16: 0$ and iso $\mathrm{C} 17: 0$ ), of $\mathrm{t}-11-\mathrm{C} 18: 1$, of cis-9, trans-11-CLA, of long chain FAs $(\geq \mathrm{C} 20)$ and by the lowest $\mathrm{C} 18: 2 / \mathrm{C} 18: 3$ ratio (Table 4$)$.

\subsection{Changes in milk production and milk composition during the year}

The "period" effect was significant for most of the milk parameters measured. Milk composition from "Corn silage+flaxseed" system was the most constant during the year.

For the three systems, calcium content decreased significantly in May (Table 3). NPN content increased significantly in May for the three systems and in September for the "Herbage" system.

Among milk FAs, short-odd-chain FAs in milk from the "Herbage" system were the ones with a specific evolution during the year. Their content increased in May, whereas it decreased as the year progressed for the "Corn silage" system. In May, trans-11-C18:1 and cis-9, trans-11-CLA increased for the "Herbage" system and in a 


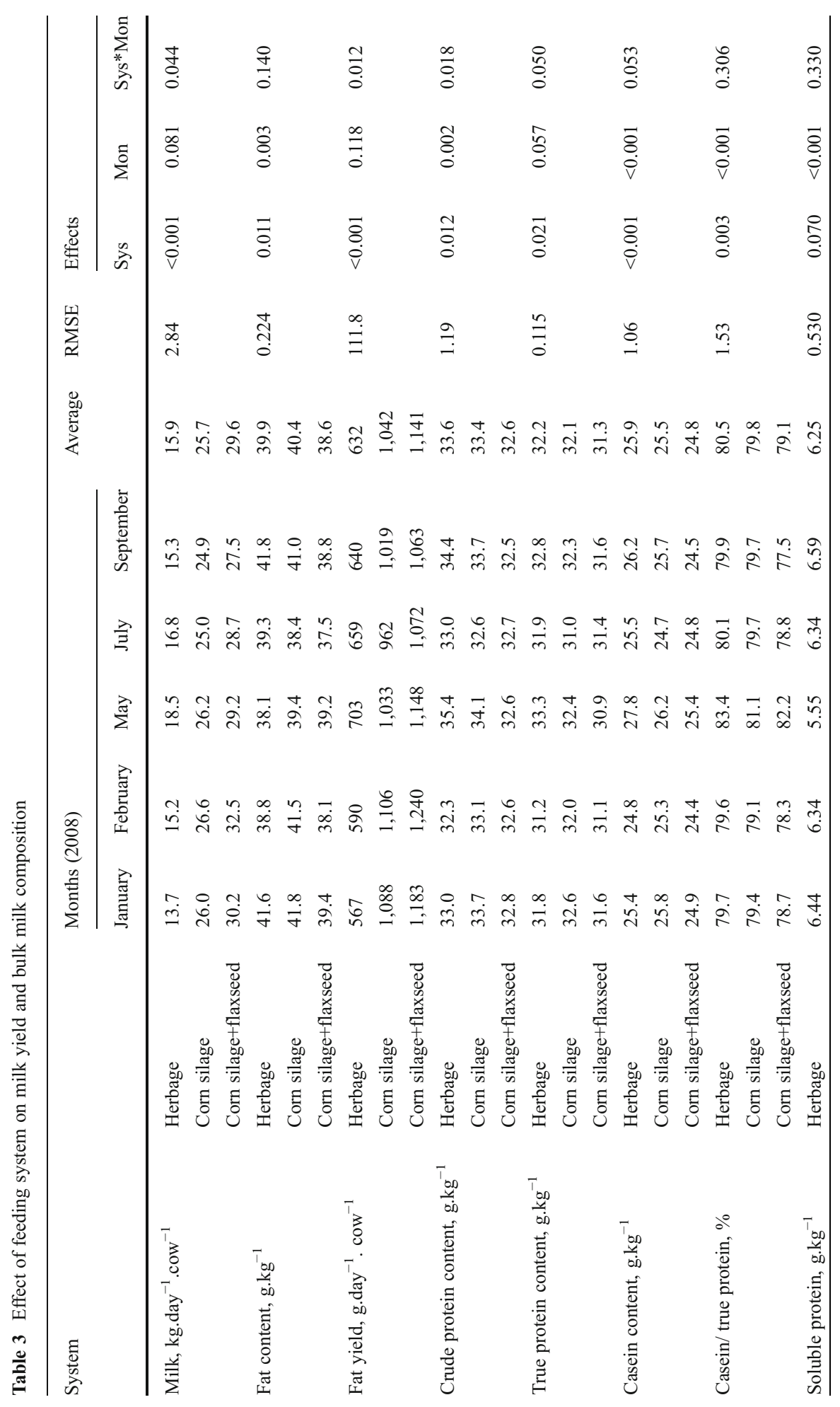




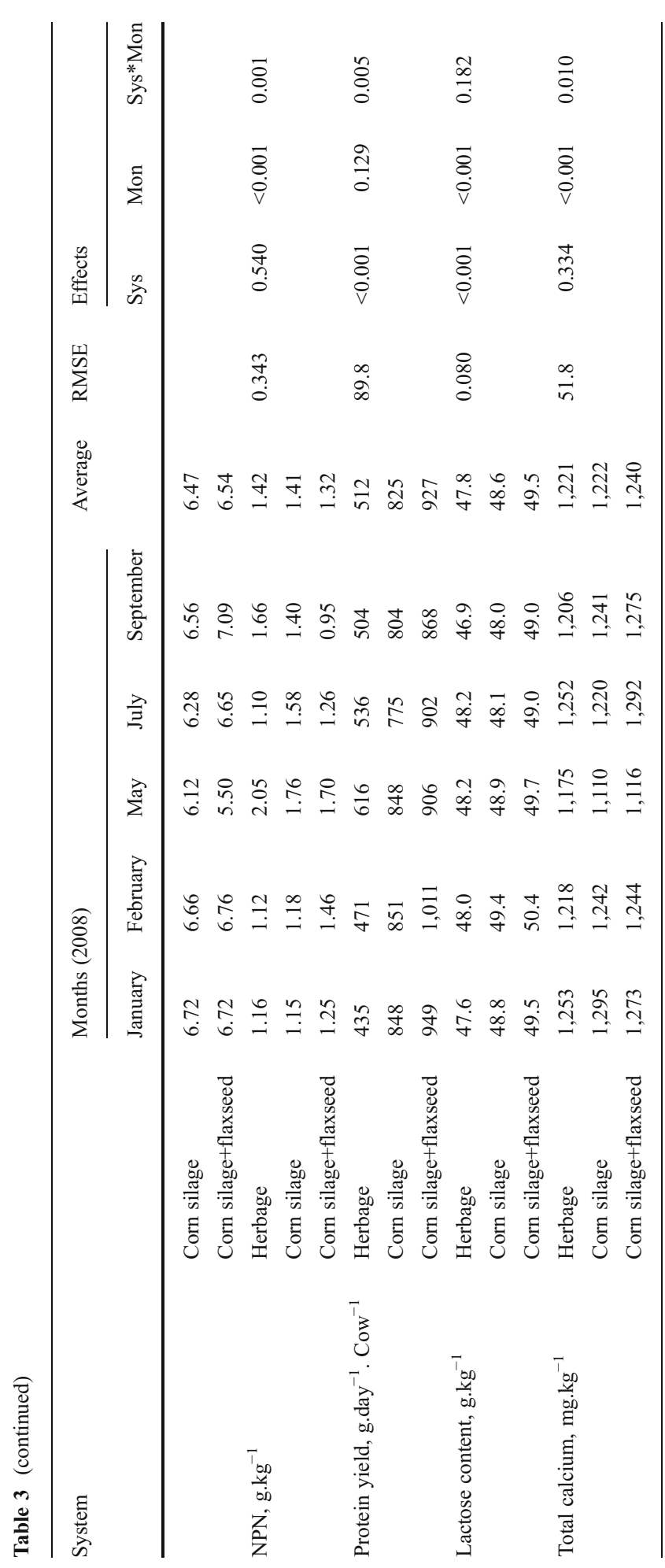


Table 4 Effect of feeding system on some milk fatty acids

\begin{tabular}{|c|c|c|c|c|c|c|}
\hline Fatty acid (g/100 g FA) & Herbage & $\begin{array}{l}\text { Corn } \\
\text { silage }\end{array}$ & $\begin{array}{l}\text { Corn silage }+ \\
\text { flaxseed }\end{array}$ & SEM & Fishers' $F$ & $\begin{array}{l}\text { System } \\
\text { effect }\end{array}$ \\
\hline $\mathrm{C} 4: 0$ & $4.59 \mathrm{a}$ & $4.43 \mathrm{ab}$ & $4.39 b$ & 0.032 & 4.0 & $<0.05$ \\
\hline $\mathrm{C} 5: 0$ & 0.023 & 0.023 & 0.018 & 0.001 & 2.5 & $<0.1$ \\
\hline C6:0 & $2.43 \mathrm{a}$ & $2.42 \mathrm{ab}$ & $2.29 \mathrm{~b}$ & 0.021 & 3.6 & $<0.05$ \\
\hline $\mathrm{C} 7: 0$ & $0.016 \mathrm{~b}$ & $0.024 \mathrm{a}$ & $0.018 \mathrm{~b}$ & 0.001 & 18.6 & $<0.001$ \\
\hline $\mathrm{C} 8: 0$ & $1.37 \mathrm{a}$ & $1.41 \mathrm{a}$ & $1.29 \mathrm{~b}$ & 0.013 & 6.2 & $<0.01$ \\
\hline C9:0 & $0.02 \mathrm{~b}$ & $0.03 \mathrm{a}$ & $0.02 b$ & 0.001 & 27.2 & $<0.001$ \\
\hline $\mathrm{C} 10: 0$ & $2.86 \mathrm{~b}$ & $3.12 \mathrm{a}$ & $2.7 \mathrm{~b}$ & 0.034 & 15.1 & $<0.001$ \\
\hline cis-9-C10:1 & $0.29 b$ & $0.3 \mathrm{~b}$ & $0.24 \mathrm{a}$ & 0.004 & 26.4 & $<0.001$ \\
\hline $\mathrm{C} 11: 0$ & $0.04 b$ & $0.07 \mathrm{a}$ & $0.04 b$ & 0.002 & 29.1 & $<0.001$ \\
\hline $\mathrm{C} 12: 0$ & $3.18 \mathrm{~b}$ & $3.57 \mathrm{a}$ & $2.96 \mathrm{~b}$ & 0.042 & 22.2 & $<0.001$ \\
\hline cis-9-C12:1 & $0.076 \mathrm{~b}$ & $0.083 \mathrm{a}$ & $0.058 \mathrm{c}$ & 0.002 & 26.6 & $<0.001$ \\
\hline C13:0 & $0.1 \mathrm{~b}$ & $0.11 \mathrm{a}$ & $0.09 \mathrm{~b}$ & 0.002 & 21.1 & $<0.001$ \\
\hline $\mathrm{C} 14: 0$ & $10.86 b$ & $11.43 \mathrm{c}$ & $10.34 \mathrm{a}$ & 0.082 & 15.1 & $<0.001$ \\
\hline iso $\mathrm{C} 15: 0$ & $0.40 \mathrm{a}$ & $0.25 b$ & $0.22 \mathrm{c}$ & 0.009 & 161.8 & $<0.001$ \\
\hline anteiso $\mathrm{C} 15: 0$ & $0.65 \mathrm{a}$ & $0.46 \mathrm{~b}$ & $0.42 b$ & 0.013 & 74.1 & $<0.001$ \\
\hline cis-9-C14:1 & $1.04 \mathrm{~b}$ & $1.15 \mathrm{a}$ & $0.93 \mathrm{c}$ & 0.016 & 16.6 & $<0.001$ \\
\hline $\mathrm{C} 15: 0$ & $1.35 \mathrm{a}$ & $1.11 \mathrm{~b}$ & $0.92 \mathrm{c}$ & 0.019 & 84.8 & $<0.001$ \\
\hline iso $\mathrm{C} 16: 0$ & $0.31 \mathrm{a}$ & $0.24 b$ & $0.25 b$ & 0.005 & 24.6 & $<0.001$ \\
\hline $\mathrm{C} 16: 0$ & $29.15 b$ & $31.93 \mathrm{a}$ & $26.63 \mathrm{c}$ & 0.316 & 27.3 & $<0.001$ \\
\hline iso $\mathrm{C} 17: 0$ & $0.59 \mathrm{a}$ & $0.42 \mathrm{~b}$ & $0.38 \mathrm{~b}$ & 0.014 & 29.9 & $<0.001$ \\
\hline cis-9-C16:1 & $1.45 b$ & $1.71 \mathrm{a}$ & $1.33 \mathrm{c}$ & 0.023 & 33.0 & $<0.001$ \\
\hline $\mathrm{C} 17: 0$ & $0.72 \mathrm{a}$ & $0.54 b$ & $0.49 \mathrm{~b}$ & 0.012 & 61.1 & $<0.001$ \\
\hline $\mathrm{C} 18: 0$ & $9.67 b$ & $8.77 \mathrm{c}$ & $10.89 \mathrm{a}$ & 0.133 & 22.6 & $<0.001$ \\
\hline trans $-6+$ trans $-7+$ trans $-8-C 18: 1$ & $0.14 \mathrm{c}$ & $0.17 b$ & $0.38 \mathrm{a}$ & 0.010 & 74.2 & $<0.001$ \\
\hline trans-9-C18:1 & $0.16 b$ & $0.17 b$ & $0.30 \mathrm{a}$ & 0.006 & 86.1 & $<0.001$ \\
\hline trans-10-C18:1 & $0.10 \mathrm{c}$ & $0.22 b$ & $0.35 \mathrm{a}$ & 0.010 & 105.3 & $<0.001$ \\
\hline trans-11-C18:1 (vaccenic acid) & $2.38 \mathrm{a}$ & $1.2 \mathrm{~b}$ & $2.29 \mathrm{a}$ & 0.100 & 22.5 & $<0.001$ \\
\hline trans-12-C18:1 & 0.01 & 0.01 & 0.01 & 0.002 & 1.1 & $>0.1$ \\
\hline cis-9-C18:1 & $19.1 b$ & $18.7 \mathrm{~b}$ & $21.18 \mathrm{a}$ & 0.210 & 9.6 & $<0.001$ \\
\hline trans-15+cis-11-C18:1 & $0.73 \mathrm{c}$ & $0.84 b$ & $1.18 \mathrm{a}$ & 0.020 & 56.7 & $<0.001$ \\
\hline cis-12-C18:1 & $0.13 \mathrm{c}$ & $0.27 b$ & $0.60 \mathrm{a}$ & 0.016 & 340.9 & $<0.001$ \\
\hline cis-13-C18:1 & $0.05 \mathrm{c}$ & $0.07 b$ & $0.10 \mathrm{a}$ & 0.003 & 15.1 & $<0.001$ \\
\hline cis-15-C18:1 & $0.08 b$ & $0.08 b$ & $0.22 \mathrm{a}$ & 0.006 & 121.8 & $<0.001$ \\
\hline C18:2 n-6 & $0.97 \mathrm{~b}$ & $1.32 \mathrm{a}$ & $1.44 \mathrm{a}$ & 0.026 & 49.0 & $<0.001$ \\
\hline Sum other isomers of $\mathrm{C} 18: 2$ & $0.76 \mathrm{~b}$ & $0.56 \mathrm{c}$ & $1.17 \mathrm{a}$ & 0.030 & 45.2 & $<0.001$ \\
\hline $\mathrm{C} 20: 0$ & $0.13 \mathrm{a}$ & $0.08 b$ & $0.11 b$ & 0.004 & 22.2 & $<0.001$ \\
\hline C18:3 n-3 (ALA) & $0.78 \mathrm{a}$ & $0.44 b$ & $0.78 \mathrm{a}$ & 0.021 & 67.6 & $<0.001$ \\
\hline $\mathrm{C} 20: 1$ & $0.10 \mathrm{a}$ & $0.07 b$ & $0.05 b$ & 0.005 & 6.3 & $<0.001$ \\
\hline $\begin{array}{l}\text { cis-9, trans-11-CLA } \\
\text { (rumenic acid) }\end{array}$ & $0.86 a$ & $0.44 \mathrm{c}$ & $0.75 b$ & 0.033 & 25.7 & $<0.001$ \\
\hline Other isomers CLA group & $0.13 \mathrm{a}$ & $0.05 b$ & $0.09 \mathrm{ab}$ & 0.007 & 15.2 & $<0.001$ \\
\hline
\end{tabular}


Table 4 (continued)

\begin{tabular}{lllllrl}
\hline Fatty acid (g/100 g FA) & Herbage & $\begin{array}{l}\text { Corn } \\
\text { silage }\end{array}$ & $\begin{array}{l}\text { Corn silage+ } \\
\text { flaxseed }\end{array}$ & SEM & Fishers' $F$ & $\begin{array}{l}\text { System } \\
\text { effect }\end{array}$ \\
\hline Long chain FA (>C20:0) & $1.16 \mathrm{a}$ & $0.74 \mathrm{~b}$ & $0.88 \mathrm{~b}$ & 0.028 & 38.4 & $<0.001$ \\
Unknown FA & $1.01 \mathrm{~b}$ & $0.93 \mathrm{c}$ & $1.19 \mathrm{a}$ & 0.016 & 21.4 & $<0.001$ \\
Saturated FA & $68.45 \mathrm{~b}$ & $70.44 \mathrm{a}$ & $64.42 \mathrm{c}$ & 0.322 & 32.8 & $<0.001$ \\
Mono unsaturated FA & $25.84 \mathrm{~b}$ & $25.04 \mathrm{~b}$ & $29.23 \mathrm{a}$ & 0.254 & 22.4 & $<0.001$ \\
Poly unsaturated FA & $3.54 \mathrm{~b}$ & $2.85 \mathrm{c}$ & $4.28 \mathrm{a}$ & 0.074 & 44.9 & $<0.001$ \\
Odd FA & $3.92 \mathrm{a}$ & $3.04 \mathrm{~b}$ & $2.60 \mathrm{c}$ & 0.059 & 107.9 & $<0.001$ \\
Short-chain FA (C4 to C10) & $11.31 \mathrm{~b}$ & $11.46 \mathrm{a}$ & $10.71 \mathrm{c}$ & 0.808 & 6.2 & $<0.05$ \\
Branched chain FA & $1.95 \mathrm{a}$ & $1.37 \mathrm{~b}$ & $1.26 \mathrm{~b}$ & 0.036 & 85.0 & $<0.001$ \\
Sum trans FA & $3.53 \mathrm{~b}$ & $2.62 \mathrm{c}$ & $4.51 \mathrm{a}$ & 0.112 & 27.3 & $<0.001$ \\
cis-9-C18:1/C18:0 & $2.00 \mathrm{~b}$ & $2.14 \mathrm{a}$ & $1.96 \mathrm{~b}$ & 0.021 & 7.6 & $<0.001$ \\
cis-9-C14:1/C14:0 & $0.096 \mathrm{~b}$ & $0.101 \mathrm{a}$ & $0.09 \mathrm{~b}$ & 0.001 & 7.4 & $<0.001$ \\
cis-9-C16:1/C16:0 & $0.050 \mathrm{~b}$ & $0.054 \mathrm{a}$ & $0.050 \mathrm{~b}$ & 0.000 & 9.8 & $<0.001$ \\
cis-9-C18:1 /C16:0 & $0.667 \mathrm{~b}$ & $0.594 \mathrm{a}$ & $0.806 \mathrm{c}$ & 0.013 & 21.1 & $<0.001$ \\
C18:2/C18:3 & $1.3 \mathrm{~b}$ & $3.62 \mathrm{a}$ & $1.9 \mathrm{~b}$ & 0.142 & 55.3 & $<0.001$ \\
\hline
\end{tabular}

Means within row with no common lowercase letters differ $(P<0.05)$. Values reported correspond to the average of five samples collected between January and September 2008

lesser extent for the "Corn silage" system due to herbage in the diet (Fig. 1). ALA content only increased for the "Corn silage" system. Long-chain FAs $(>\mathrm{C} 20)$ increased in May for the "Herbage" system. Values of other FAs, such as linear odd medium chain FAs and C18:1 isomers (except cis-9 and trans-11-C18:1), didn't change during the year $(P>0.05)$, but were very different for the three systems $(P<0.05)$. The changes in palmitic acid during the year were the same for the "Herbage" and "Corn silage" system with a decrease in May, whereas it stayed relatively constant for the "Corn silage+ flaxseed" system.

\subsection{Authentication of farm system through milk FAs}

The most discriminant FAs were iso C15, trans-10-C18:1, cis-12-C18:1, cis-15C18:1, odd FAs and branched chain FAs (Table 4). Milk from the "Herbage" system was characterized by a lower content in trans-10-C18:1, cis-12-C18:1 and cis-13C18:1 and a higher content in iso C15, cis-9, trans-11 CLA, odd and branched chain FAs compared to the milk from the two other systems. Milk from the "Corn silage" system had a lower content in trans-10-C18:1, cis-12 and cis-15-C18:1 and a higher content of odd FAs compared to milk from the "Corn silage+flaxseed" system.

The LDA performed with FAs having Fischer's $F$ values higher than 20 from the GLM ANOVA (Table 4) clearly separates "Herbage" system from "Corn silage+ flaxseed" on the first linear discriminant function (LD) explaining $74.1 \%$ of total variance. The second LD explained $24.9 \%$ of total variance and contributed to the segregation of "Corn silage" system from the two others feeding systems (Fig. 2). The LD1 was positively correlated to the main branched chain FA and odd FA 

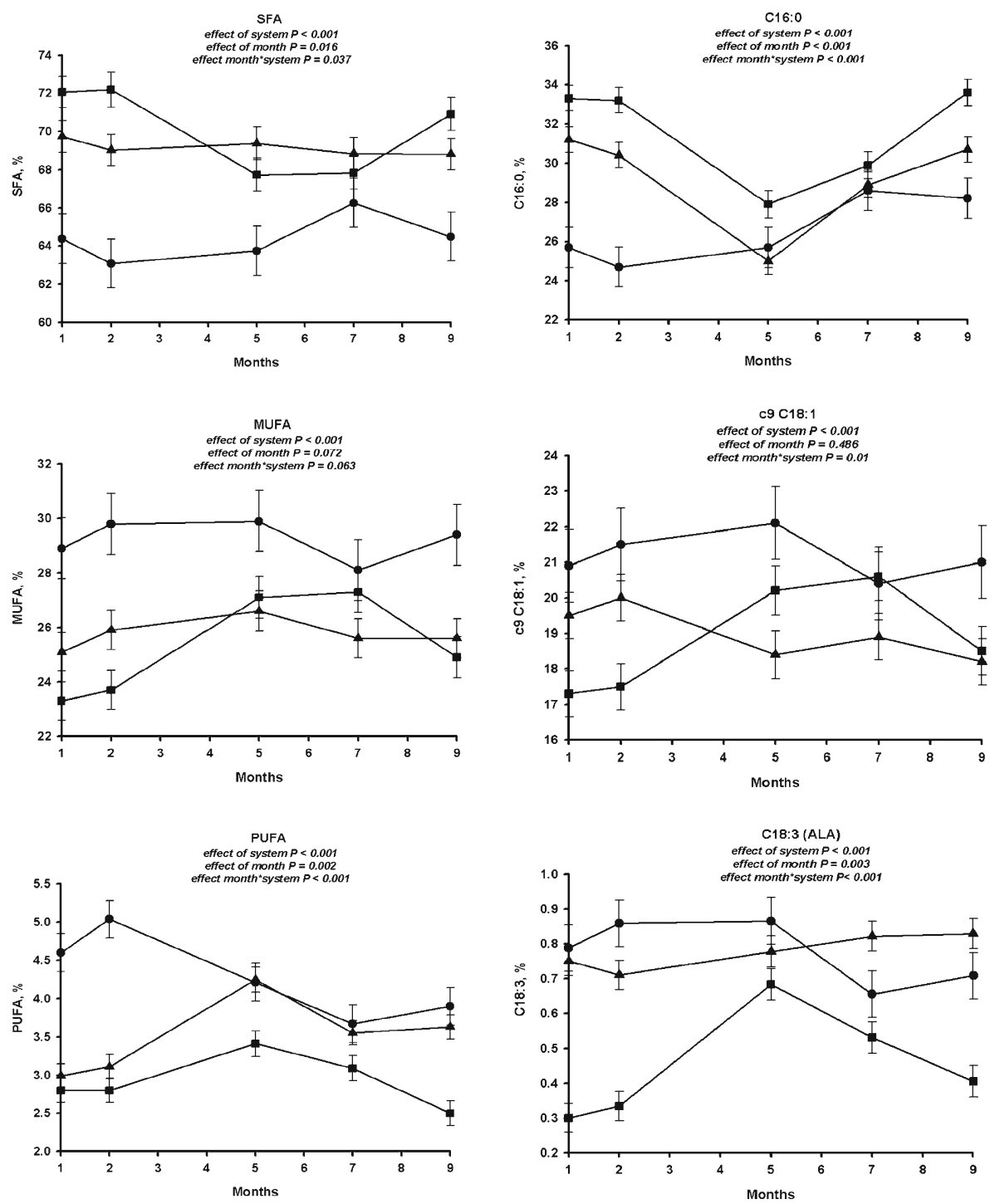

Fig. 1 Effect of feeding system and month on milk fatty acids (black triangle: "Herbage system", ten farms; black square: "Corn silage system, ten farms; black circle: "Corn silage+flaxseed system", four farms). Values are indicated in grams per $100 \mathrm{~g}^{-1}$ FA. Bars indicate standard deviations

(C15:0, iso $\mathrm{C} 15: 0$, anteiso $\mathrm{C} 15: 0, \mathrm{C} 17: 0$, iso $\mathrm{C} 17: 0$, iso $\mathrm{C} 16: 0)$, and negatively to trans-10-C18:1, cis-12-C18:1, trans-15+cis-11-C18:1, and C18:2 n-6. LD2 was positively correlated to all the other $\mathrm{C} 18: 1$ isomers (trans-6+trans-7+trans-8-C18:1, trans-9-C18:1, trans-11-C18:1, and cis-15-C18:1), and poly-unsaturated FA (cis-9, trans-11 CLA, sum of isomers of C18:2, and ALA), and to long chain saturated FAs (C18:0, and C20:0), and negatively correlated to medium chain saturated and monounsaturated FAs (C9:0, C10:0, cis-9-C10:1, C11:0, C12:0, cis-9-C12:1, C13:0, $\mathrm{C} 16: 0$, and cis-9-C16:1). 

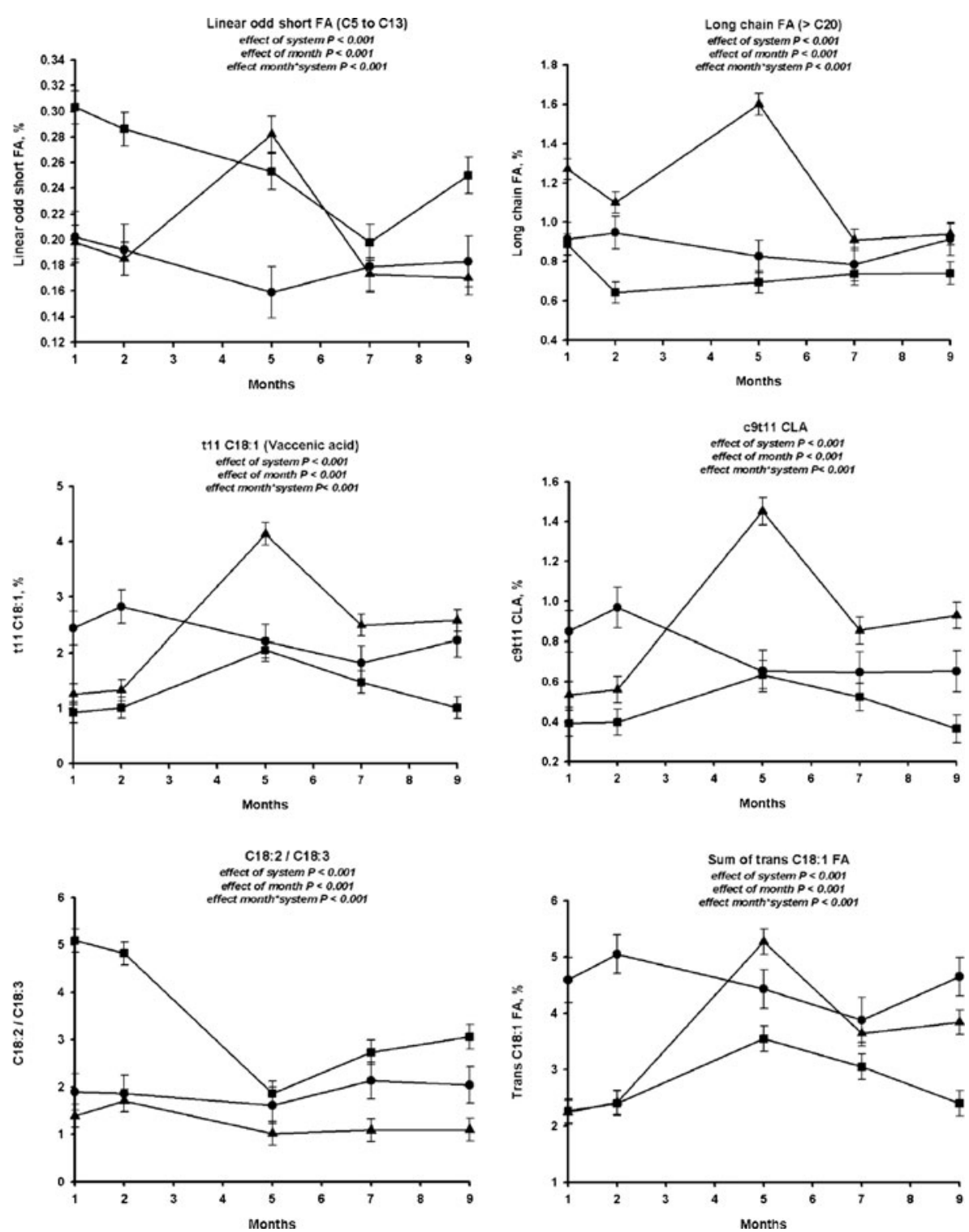

Fig. 1 (continued)

The LDA correctly classified a priori all samples of "Corn silage" and "Herbage" systems ( $100 \%$ of sample correctly classified). Just one milk sample from "Corn silage+ flaxseed" system was incorrectly assigned to "Corn silage" group (95\% of samples correctly classified). A second "Corn silage+flaxseed" system milk was incorrectly assigned to "Corn silage" group by cross-validation ( $90 \%$ of samples correctly classified), as well as one sample from "Corn silage" system was incorrectly assigned to "Herbage" system (98\% of samples correctly classified). By contrast, "Herbage" system milk was not misclassified in "Corn silage+flaxseed" (and vice versa), neither by the a priori classification nor by cross-validation. 


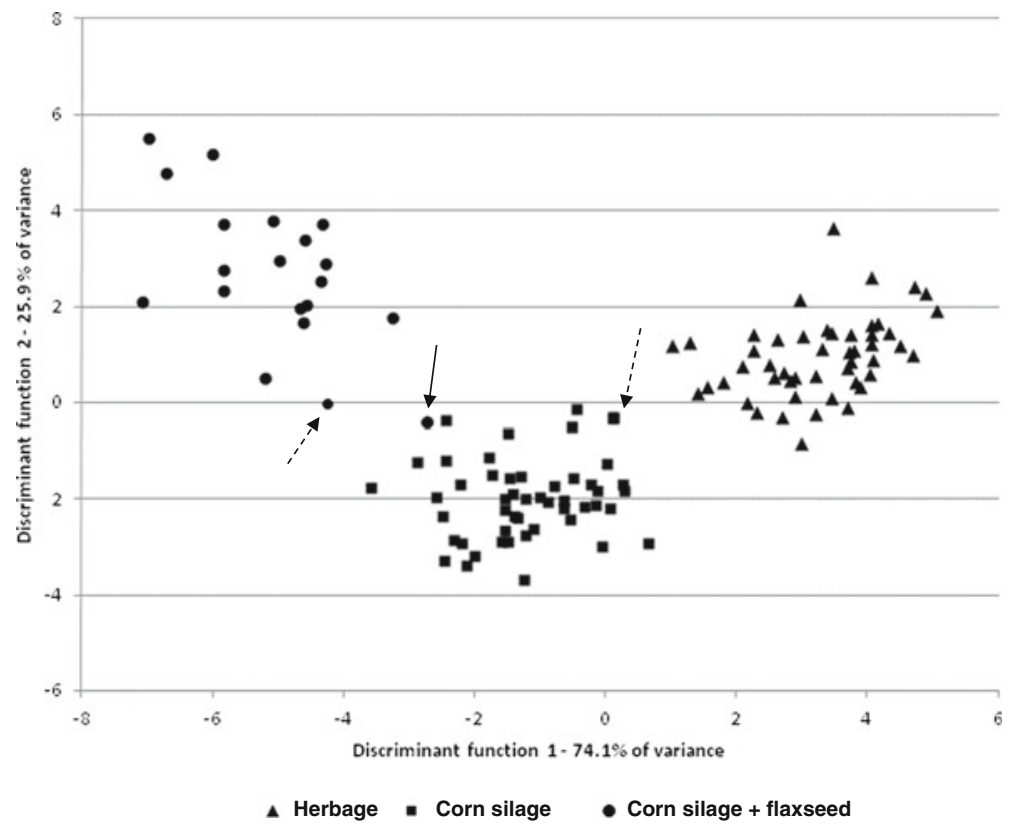

Fig. 2 Distribution of milk samples according to the Linear Discriminant Analysis. Incorrectly classified a priori samples are indicated by a full arrow, while dashed arrows indicate samples incorrectly classified by cross-validation. "Herbage system": 50 samples, "Corn silage system": 50 samples, "Corn silage+flaxseed system": 20 samples

\section{Discussion}

\subsection{Feeding system, milk production and composition}

Compared to the farms in the "Corn silage" system, farms in the "Herbage" system had lower milk production and lactose content, higher protein content and the same fat content. Results on milk production and fat content are similar to results found by Delaby et al. (2009) in an experiment comparing different feeding strategies based on corn silage with high amounts of concentrates or on herbage (grazed or preserved) with low amounts of concentrates. The reduction in milk yield especially during winter period, due to the decrease in the level of energy intake, is consistent with the results of Coulon and Rémond (1991). The "Herbage" system led to an increased percentage of long chain and unsaturated FAs at the expense of short- and medium-chain and saturated FAs. The effect of diet on the FA profile is consistent with the literature (Chilliard et al. 2007; Coppa et al. 2013). The effect of pasture on CLA c9t11 is specific (Hurtaud et al. 2010a). Milk c9t11 CLA content increases with increasing proportions of pasture in the $\operatorname{diet}$ (Collomb et al. 2006; Couvreur et al. 2006; Coppa et al. 2013). The CLA-enriching effect of pasture has been attributed to the effects on bio-hydrogenation and the provision of ALA as a lipid substrate for the formation of vaccenic acid (trans-11$\mathrm{C} 18: 1$ ) in the rumen (which also increased in our trial) and its subsequent desaturation to cis-9-trans-11-CLA in the mammary gland (Bauman and Griinari 2003). Milk from the "Herbage" system was characterized by a high content in branched chain FAs due to changes in rumen fermentations. Coppa et al. (2013) observed on farm a decrease in 
bulk milk branched chain FAs content at increasing corn silage and at decreasing herbage (fresh or conserved). According to Vlaeminck et al. (2006a), replacing corn silage with herbage silage decreased dietary starch and increased dietary neutral detergent fiber, which could substantially affect rumen $\mathrm{pH}$, microbial populations and proportions of volatile fatty acids produced leading to an increase in milk iso C14:0 and iso $\mathrm{C} 15: 0$ content.

Compared to the farms in the "Corn silage" system, farms in the "Corn silage+ flaxseed" system had higher milk production and lactose content, and lower fat and protein contents. Hurtaud et al. (2010b) observed the same increase in milk production and decrease in protein and fat contents with an increasing amount of extruded flaxseed in the diet. According to Caroprese et al. (2010), flaxseed supplementation improved energy utilization for milk synthesis. The lower protein content could be a consequence of the higher milk production since total protein yield was significantly higher for the "Corn silage+flaxseed" system (dilution effect). The lower fat content might also result from a dilution effect or from a lower synthesis of short- and medium-chain FAs. A slower rate of mammary lipogenesis might occur as a result of adding polyunsaturated lipids to a diet rich in starch (Chilliard et al. 2007, 2009). This is consistent with the observed differences in milk FA profiles, especially the higher proportions of C18:1 isomers (cis and trans; Fig. 1). We particularly observed a higher trans-10-C18:1 content in milk from "Corn silage+flaxseed" system, but the difference was not as important as reported by Chilliard et al. (2009), maybe because of the lower quality of flaxseeds that were supplemented in our trial. The increase in content of C18:1 isomers can be the result of partial biohydrogenation of C18:2 (main fatty acid of corn silage) and C18:3 (main fatty acid of flaxseed) in the rumen (Chilliard et al. 2007).

Compared to milk from the "Herbage" system, milk from the "Corn silage+flaxseed" system can mostly be differentiated based on its composition of FAs. Differences observed between milk from the "Corn silage+flaxseed" system and the "Herbage" system for the isomers of C18:1 (except trans-11 and cis-9) and the odd and branched chain FAs are more obvious than differences between the "Corn silage" system and the "Corn silage+flaxseed" system. The reason of this difference is that in the "Corn silage+ flaxseed" system, the quantity of herbage fed to the cows (especially from grazing) is lower and the quantity of concentrates is higher compared to the "Herbage" system.

\subsection{Changes in milk production and composition during the year}

Milk composition from the "Corn silage+flaxseed" system is more constant during the year than milk composition from the two other systems. The seasonal effect is less obvious since feeding does not change a lot during the year.

Results regarding milk production, milk fat content and milk protein content are not discussed here because there are well-known results. The focus will be on NPN content, calcium and some specific FAs in the milk.

The evolution of the NPN content in the milk complies with the results from Heck et al. (2009) who showed that NPN is also maximized in summer in dairy farms from Holland studied during 1 year. This is probably due to the fact that cows are eating fresh herbage rich in nitrogen. The decrease in milk calcium content in May could be due to a rapid increase in temperature. Indeed, in spring 2008, large changes in temperature were observed within 1 day (up to $10^{\circ} \mathrm{C}$ ) at a time when cows were outside most of the day, 
sometimes night and day. Heat stress induced accelerated respiration rate causing respiratory alkalosis. Alkalosis caused a change in hydrogen bounding of blood proteins, attracting free ionized calcium, and reducing calcium available for mammary gland (Sanchez et al. 1994). The seasonal effect on odd short chain FAs (C5:0 to C13:0) could result from the changes in VFAs in the rumen. Vlaeminck et al. (2004) found a positive relationship between $\mathrm{C} 15: 0$ and rumen proportions of propionate. This suggests that rumen conditions inducing high propionate production are favorable for bacteria synthesizing linear odd-chain fatty acids. High proportions of propionate might have stimulated de novo synthesis of linear odd-chain fatty acids from propionyl-CoA in the mammary gland (Vlaeminck et al. 2006b). The transition from hay in winter to grazing in spring could lead to an increase in propionic acid in the rumen for cows in the "Herbage" system, whereas the transition from corn silage to grazing could have the opposite effect for cows in the "Corn silage" system (less starch in the diet due to the change in forage and the decrease in concentrates during spring) (Vlaeminck et al. 2004). The increase in trans-11-C18:1 and cis-9, trans-11-CLA content could be linked to the addition of pasture in the diet (Dhiman et al. 1999; Leiber et al. 2005; Couvreur et al. 2006). The milk ALA content for the "Herbage" system was only slightly higher during the grazing season (and in particular in May), compared to the winter season. Even if an increase in milk ALA content could be expected at increasing fresh herbage proportion in cow diet (Couvreur et al. 2006; Collomb et al. 2008; Coppa et al. 2013), according to Ferlay et al. (2006), milk ALA content can be similar for the cows fed hay or fresh herbage, sometimes even higher for hay-based diets (1.9 vs. $1.1 \mathrm{~g} / 100 \mathrm{~g} \mathrm{FA})$. Even though hay is less rich in ALA than fresh herbage (14.6\% vs $39.9 \%$ of the FA, Doreau and Poncet 2000), it can induce, in fact, higher transfer rate to milk than fresh herbage (Chilliard et al. 2007). This may be due to a protective factor in hay that would limit ALA bio-hydrogenation in the rumen.

\subsection{Authentication of feeding system through milk FAs}

The LDA correctly classified a priori all samples of "Corn silage" and "Herbage" systems ( $100 \%$ of samples correctly classified). Just one milk sample from "Corn silage+flaxseed" system was incorrectly assigned to "Corn silage" group (95\% of samples correctly classified) because of its lower proportion in cis-9-C18:1, isomers of C18:1, C18:2, isomers of $\mathrm{C} 18: 2, \mathrm{C} 18: 3$ and cis9, trans-11-CLA than the other samples from the same group. As no difference in forage proportions was observed for the diet from which this sample derived, compared to the other samples of the same group, this misclassification may be explained by differences in forage quality, and in particular in fresh herbage quality. Indeed, cows that produced this milk were grazing at the end of a paddock when a decrease in herbage quality (lower leaves to stem proportion, higher fiber content, lower fat and ALA content in herbage) is often reported (Abrahamse et al. 2008; Coppa et al. 2011) and was associated by Vlaeminck et al. (2010) to a lower concentration of the previously cited FAs in milk. Similar results were observed by Coppa et al. (2011) and Vlaeminck et al. (2010): the variation of FA composition of milk from grazing cows on continuous and rotational grazing systems was related to the evolution of herbage chemical composition and phenological stage. A second milk sample from "Corn silage+flaxseed" system was incorrectly assigned to "Corn silage" group by crossvalidation ( $90 \%$ of samples correctly classified) due most likely to the lack of extruded 
flaxseed in cow diet for a short time just before milk sampling. One sample from "Corn silage" system was incorrectly assigned to "Herbage" system (98\% of samples correctly classified). This is directly related to the feeding management at that time: corn silage was not fed to the cows during a short period just before milk sampling. They only received herbage from pasture and hay, as the cows in the "Herbage" system. By contrast, "Herbage" system milk was not misclassified in "Corn silage+flaxseed" system (and vice versa), neither by the a priori classification nor by cross-validation. This result is quite unexpected since supplementing corn silage with extruded flaxseed is viewed as an alternative to grazing inducing quite the same milk FAs composition. Flaxseed supplementation, in fact, can increase the milk content in ALA, for which high concentrations are also typical of herbage-derived milk. However trans FA are higher with flaxseed supplementation than with herbage. Milk from the "Herbage" system can be differentiated from milk from the "Corn silage+flaxseed" system mainly based on 7 FAs or group of FAs: trans-10-C18:1, cis-12-C18:1 and cis-15-C18:1, cis-9, trans-11 CLA, iso C15, odd and branched chain FAs. Those two systems were associated with a high milk content in ALA coming from the extruded flaxseed or from the herbage fed to the cows. However, this FA in feeds can follow different biohydrogenation pathways in the rumen, according to the main forage composing cow diet, to the forage to concentrate ratio and to the diet starch concentrate (Bauman and Griinari 2003; Chilliard et al. 2007), resulting in different proportion of biohydrogenation intermediates. The feeding management in the "Herbage" system, in which fresh herbage and hay were abundant in cow diet, leads to an increase in ALA, in branched chain FAs and cis-9, trans-11-CLA and so, improves the nutritional quality of milk fat (Williams 2000). By contrast, the feeding management in the "Corn silage+flaxseed" system was associated with an increase in ALA. This system is also associated with isomers of C18:1 (trans-10-C18:1, cis-12-C18:1 and cis-15-C18:1) for which the impacts on human health are unknown.

\section{Conclusion}

This study clarified the link between feeding management systems in Western France and milk composition, especially milk FAs. Two main feeding systems were interesting regarding milk FA profiles: a feeding system based on herbage (fresh or preserved), and a feeding system based on corn silage supplemented with extruded flaxseed. Nevertheless, we showed that it is possible to characterize milk from those systems and especially to differentiate one from another based on their composition of some milk FAs. Both had a high ALA content but milk from the "Corn silage+ flaxseed" system was rich in isomers of C18:1 and C18:2, whereas milk from the "Herbage" system was rich in branched chain FAs and CLA. Milk composition from "Corn silage+flaxseed" system remained constant during the year, little changes due to feeding management were observed, which is what the milk-processing plants are looking for in France. By contrast, milk from the "Herbage" system is cheap to produce in lowland in France (Charroin et al. 2004), has a positive environmental impact and a good image for consumers.

Acknowledgments This research was supported in part by the European TRUEFOOD program (Traditional United Europe Food), an integrated project funded by the European Commission under the 6th Framework 
Program for RTD (Contract No. FOODCT-2006-016264). We thank all of the farmers from Ille et Vilaine department (France) who collaborated in the surveys. We also thank N. Huchet, T. Le Mouël and M. Vérité for their technical assistance. This work was carried out under the partnership between INRA and the "Institut de l'Elevage" within the UMT RIEL.

\section{References}

Abrahamse PA, Dijkstra J, Vlaeminck B, Tamminga S (2008) Frequent allocation of rotationally grazed dairy cows changes grazing behavior and improves productivity. J Dairy Sci 91:2033-2045

AFNOR NF V04-210 (2000) Lait - Détermination de la teneur en matière grasse - Méthode acidobutyrométrique. Afnor, Paris, France

AFNOR NF V04-216 (2011) Lait - Détermination de la teneur en protéines vraies - Méthode au noir amido (méthode pratique). Afnor, Paris, France

Alais C (1984) Les protides du lait. La caséine et le phénomène de coagulation. P 107 in Science du lait, principe des techniques laitières, SEPAIC ed, Paris, France

Bauchart D, Duboisset F (1983) Utilisation des colonnes capillaires de verre pour l'analyse des acides gras du lait. Cah Techn INRA 1:37-46

Bauman DE, Griinari JM (2003) Nutritional regulation of milk fat synthesis. Annu Rev Nutr 23:203-227

Brûlé G, Maubois JL, Fauquant J (1974) Etude de la teneur en minéraux des produits obtenus lors de l'ultrafiltration du lait sur membrane. Lait 54:600-615

Brunschwig P, Hurtaud C, Chilliard Y, Glasser F (2010) L'apport de lin dans la ration des vaches laitières: Effets sur la production, la composition du lait et des produits laitiers, les émissions de méthane et les performances de reproduction. INRA Prod Anim 23:307-318

Caroprese M, Marzano A, Marino R, Gliatta G, Muscio A, Sevi A (2010) Flaxseed supplementation improves fatty acid profile of cow milk. J Dairy Sci 93:2580-2588

Charroin T, Capitain M, Perrot C (2004) Le coût de production du lait en France dans les exploitations spécialisées, évolution de 1990 à 2001. Renc Rech Rumin 11:189-192

Chilliard Y, Glasser F, Ferlay A, Bernard L, Rouel J, Doreau M (2007) Diet, rumen biohydrogenation and nutritional quality of cow and goat milk fat. Eur J Lipid Sci Technol 109:828-855

Chilliard Y, Martin C, Rouel J, Doreau M (2009) Milk fatty acids in dairy cows fed whole crude linseed, extruded linseed, or linseed oil, and their relationship with methane output. J Dairy Sci 92:5199-5211

Clare DA, Swaisgood HE (2000) Bioactive milk peptides: a prospectus. J Dairy Sci 83:1187-1195

C.N.I.E.L. (2013) La consommation humaine par habitant des principaux produits laitiers dans le monde. P 176 in L'économie laitière en chiffres - Edition 2013

Collomb M, Bisig W, Bütikofer U, Sieber R, Bregy M, Etter L (2008) Seasonal variation in the fatty acid composition of milk supplied to dairies in the mountain regions of Switzerland. Dairy Sci Technol 88:631-647

Collomb M, Schmid A, Sieber R, Wechsler D, Ryhänen EL (2006) Conjugated linoleic acids in milk fat: variation and physiological effects. Int Dairy J 16:1347-1361

Coppa M, Ferlay A, Monsallier F, Verdier-Metz I, Pradel P, Didienne R, Farruggia A, Montel MC, Martin B (2011) Milk fatty acid composition and cheese texture and appearance from cows fed hay or different grazing systems on upland pastures. J Dairy Sci 94:1132-1145

Coppa M, Ferlay A, Chassaing C, Agabriel C, Glasser F, Chilliard Y, Borreani G, Barcarolo R, Baars T, Kusche D, Harstad OM, Verbič J, Golecský J, Martin B (2013) Prediction of bulk milk fatty acid composition based on farming practices collected through on-farm surveys. J Dairy Sci 96:4197-4211

Coulon JB, Rémond B (1991) Variations in milk output and milk protein content in response to the level of energy supply to the dairy cow. A review. Livest Prod Sci 29:31-47

Couvreur S, Hurtaud C, Lopez C, Delaby L, Peyraud JL (2006) The linear relationship between the proportion of fresh grass in the cow diet, milk fatty acid composition, and butter properties. J Dairy Sci 89:1956-1969

Delaby L, Faverdin P, Michel G, Disenhaus C, Peyraud JL (2009) Effect of different feeding strategies on lactation performance of Holstein and Normande dairy cows. Animal 3:891-905

Dhiman TR, Anand GR, Satter LD, Pariza MW (1999) Conjugated linoleic acid content of milk from cows fed different diets. J Dairy Sci 82:2146-2156

Doreau M, Poncet C (2000) Ruminal biohydrogenation of fatty acids originating from fresh or preserved grass. Reprod Nutr Dev 40:201 
Ferlay A, Martin B, Pradel P, Coulon JB, Chilliard Y (2006) Influence of grass-based diets on milk fatty acid composition and milk lipolytic system in Tarentaise and Montbéliarde cow breeds. J Dairy Sci 89:4026-4404

Heck JML, van Valenberg HJF, Dijkstra J, van Hooijdonk ACM (2009) Seasonal variation in the Dutch bovine raw milk composition. J Dairy Sci 92:4745-4755

Hurtaud C, Agabriel C, Dutreuil M, Rouillé B (2010a) Caractérisation de la composition des laits selon les pratiques d'alimentation dans les principales régions laitières françaises. Renc Rech Rumin 17:381-384

Hurtaud C, Faucon F, Couvreur S, Peyraud JL (2010b) Linear relationship between increasing amounts of extruded linseed in dairy cow diet and milk fatty acid composition and butter properties. J Dairy Sci 93:1429-1443

Institut National de la Recherche Agronomique (INRA) (2007) Alimentation des bovins, ovins et caprins. Besoin des animaux - Valeur des aliments. Tables INRA 2007, ed. Quae, INRA, Versailles, France.

Legrand P (2010) Intérêt nutritionnel des acides gras saturés. Sci Aliment 29:115-122

Leiber F, Kreuzer M, Wettstein HR, Scheeder MRL (2005) A study on the causes for elevated n-3 fatty acids in cows' milk of Alpine origin. Lipids 40:191-202

Martin B, Hurtaud C, Graulet B, Ferlay A, Chilliard Y, Coulon JB (2009) Herbe et qualité nutritionnelle et organoleptique des produits laitiers. Fourrages 199:291-310

NF ISO 26462/FIL 214 (2010) Lait - Détermination de la teneur en lactose - Méthode enzymatique par pHmétrie différentielle. Fil, Paris, France

Nicolis RJ (1997) Dietary fat saturation effects on low-density-lipoprotein concentration and metabolism in various animal models. Am J Clin Nutr 65:597-610

Sanchez WK, McGuire MA, Beede DK (1994) Macromineral nutrition by heat stress interactions in dairy cattle. J Dairy Sci 77:2051-2079

SAS (2005) Sas Institute Inc., Cary, NC, USA

Schori F, Fragnière C, Schaeren W, Stoll W (2006) Graines de lin et de tournesol dans l'alimentation de la vache laitière. Rev Suisse Agric 38:25-30

Siri-Tarino P, Sun Q, Hu FB, Krauss MK (2010) Meta-analysis of prospective cohort studies evaluating the association of saturated fat with cardiovascular disease. Am J Clin Nutr 91:535-546

Vlaeminck B, Fievez V, Van Laar H, Demeyer D (2004) Prediction of rumen volatile fatty acid proportions produced in vitro using variations in rumen odd and branched chain fatty acids. $\mathrm{J}$ Anim Physiol Anim Nutr 88:401-411

Vlaeminck B, Fievez V, Cabrita ARJ, Fonseca AJM, Dewhurst RJ (2006a) Factors affecting odd- and branched-chain fatty acids in milk: a review. Anim Feed Sci Technol 131:389-417

Vlaeminck B, Fievez V, Tamminga S, Dewhurst RJ, Van Vuuren A, De Brabander D, Demeyer D (2006b) Milk odd- and branched-chain fatty acids in relation to the rumen fermentation pattern. J Dairy Sci 89:3954-3964

Vlaeminck B, Abrahamse PA, Fievez V, Lourenco M, Dijkstra J, Tamminga S (2010) The effect of allocation frequency in rotational grazing systems on the fatty acid profile in milk fat of dairy cows. Pages 586-588 in Grassland in a changing world. Proc. 23rd General Meeting of the European Grassland Federation, Kiel, Germany

Williams CM (2000) Dietary fatty acids and human health. Ann Zootech 49:165-180 